Сања Кобиљ һуић

sanja.kobilj@flf.unibl.org

Универзитет у Бањој Луци

Филолошки факултет https://doi.org/10.18485/knjiz.2021.11.11.7

УДК: 821.131.1.09 Мујчић Е.

Оригинални научни чланак

\title{
Језик и идентитет у роману Елвире Мујчић
}

У раду се бавимо питањем транснационалне књижевности кроз случај ауторке босанскохерцеговачког поријекла Елвире Мујчић која, као представница такозване друге генерације имигрантских писаца у Италији, пише и објављује искључиво на италијанском језику. Посебна пажња је посвећена питању језика у изградњи идентитета којим се ауторка бави у једном од својих најважнијих романа La lingua di Ana. Chi sei quando perdi radici e parole (Анин језик. Ко си када изгубиш коријене и ријечи), објављеном 2012. године. У теоријском смислу, оквир за анализу овог романа представља утицајна студија Mappings (Мапирања) Сузан Стенфорд Фридман, једне од најзначајнијих критичарки транснационалне књижевности и локацијског феминизма. Њена идеја да књижевни текст ствара теорију подразумијева да роман La lingua di Ana можемо сматрати програмским дјелом у којем је јасно дефинисано питање језика и његове везе с идентитетом, али и кључним Другим. У роману је доминантна идеја о коегзистенцији двају језика као могућности креирања односа према Другом, различитом од нас, што омогућава флуидност идентитета јунакиње, али и њено одбијање бинарних категорија постојања, што је у линији с основним поставкама локацијског феминизма. Како ћемо покушати показати у раду, језик домаћина има додатну функцију поновног рађања након трауматског егзила из језика поријекла. Како се Елвира Мујчић активно бави и књижевним превођењем, узећемо у разматрање њен есеј симболичног наслова „L’Altra“ (Друга) у којем објашњава властито схватање коезгзистенције два језика, те значаја и функције превода. Такође, овим радом се покушава указати на потребу за даљим мапирањем књижевних гласова дијаспоре, али и за довођењем у питање традиционалних категорија попут националне књижевности.

Кључне речи: транснационална/миграцијска књижевност, идентитет, impasse, канон

\section{Елвира Мујчић - представница миграцијске и транснационалне} књижевности

Елвира Мујчић рођена је у Лозници, из које се с породицом пресељава у Сребреницу, гдје ће живјети до избијања ратних сукоба, да би потом била присиљена избјећи с породицом у Италију. Тамо је завршила и школовање, а књижевни занат потврдила писањем искључиво на италијанском језику и бавећи се интензивно превођењем књижевности ауторки и аутора с простора бивше Југославије на италијански језик, што представља својеврсни феномен. На италијанском језику објавила је романе La lingua di Ana. Chi sei quando perdi radici e parole (2012), ${ }^{1}$ Dieci prugne ai fascisti (2016), Consigli per essere un bravo immigrato (2020). Спада у 
најзначајније представнике миграцијске књижевности у Италији, међу којима су и Дуња Бадњевић, Милица Маринковић, Никола П. Савић и многи други.

Захваљујући напору пионира Арманда Њишија (Armando Gnisci) који је почетком деведесетих година прошлог вијека у академске кругове увео изучавање миграцијске књижевности на италијанском језику, ${ }^{2}$ данас говоримо о три фазе миграцијске књижевности: прва, у којој настају дјела написана у коауторству с говорницима италијанског језика; друга, у којој се писци осамостаљују и објављују дјела на италијанском језику, а у овој фази настају многе издавачке куће заинтересоване за објављивање радова представника миграцијске књижевности; те посљедња, трећа фаза, којој припада и Елвира Мујчић, која обухвата другу генерацију књижевница и књижевника који су или рођени у Италији, те италијански језик доживљавају као матерњи, или су у Италију стигли у раном добу, те прошли цјелокупан образовни пут на том језику. Иако су управо дјела друге генерације миграната обогатила савремену италијанску књижевност, према ријечима Александре Вранћеану (Alexandra Vranceanu), ови писци су умјесто маргинализованог мјеста унутар самог канона измислили свој властити, транснационални простор (Vranceanu 2010: 84). У складу с овим концептом, могуће је говорити о транснационалној димензији миграцијске књижевности која представља релативно нов, али свакако актуелан методолошки оквир за изучавање све бројнијих мигрантских гласова. Транснационална књижевност обухвата комплексно питање књижевне продукције у глобализованом свијету, али као таква не искључује постојање националних књижевности. Представници ове теоретске школе баве се ауторкама и ауторима који пишу и дјелују у међупросторима између више језика и култура. Утицајна студија Mappings америчке критичарке Сузан Стенфорд Фридман (Susan Stanford Friedman), представнице локацијског феминизма, говори о геополитичкој димензији идентитета, те о потреби да се идентитет посматра као промјенљива категорија која настаје у комбинацији питања расе, рода, класе и сличних категорија. Фридман полази од идеје да књижевни текст ствара теорију, сматрајући да je са̂м идентитет „дословно незамислив без наратива“ (Friedman 1998: 8), те да „централно зависи од наратива“ (Friedman 1998: 153). Како би се идентитет освијестио, према Фридман, често је неопходан предуслов нека врста дислокације, што представља и почетну позицију кретања нараторке-протагонисткиње романа Елвире Мујчић La lingua di Ana. Chi sei quando perdi radici e parole. Пропитивање идентитета након дислокације, живот у међупростору два језика, изградња идентитета који остаје флуидан и недефинисан, те радња романа која је смјештена у фиктивни простор који није 
ауторкина земља поријекла, чиме се наглашава универзална вриједност миграцијског искуства, само су неки од елемената који овај роман чине транснационалним.

\section{Фунција језика у роману}

Роман већ од поднаслова отвара дијалог о питању идентитета, односно о улози самог језика у процесу депатријаризације. То је образовни роман о сазријевању дјевојке Ане која из Молдавије долази у Италију да живи с мајком, економском мигранткињом. Питање идентитета у адолесцентској доби само по себи је осјетљиво, али у овом роману је и додатно оптерећено осјећајем дислоцираности, те пресељењем у другу земљу, у којој се говори непознат језик. Ана поново мора да изгради однос с мајком, али и има задатак да створи нову реалност која ће имати смисла, а тај процес започиње односом према језику. Радња романа описује процес трансформације лика управо кроз прихватање језика домаћина. Ана проводи тинејџерске године у Молдавији уз двије баке и оца, док се мајка одселила у Италију у потрази за послом. Молдавија је у роману представљена са свим проблемима једне источноевропске земље: сиромаштвом, патријархалним устројством, дјецом чији су родитељи економски мигранти и због тога их одгајају баке и дједови. Сиромаштво, топлина и непосредност њених бака, уз оскудно образовање које су добиле, представљају контрапункт мајци која је у селу позната као жена која мисли својом главом и има храбрости да за себе и кћерку обезбиједи бољу будућност. Ана се по пресељењу код мајке у Италију тешко сналази у новом амбијенту, док јој се мајка чини попут странкиње. Њихов однос је конфликтан усљед Аниног осјећаја напуштености од стране мајке, али и чињенице да се она релативно интегрисала у италијанско друштво, што подразумијева да је напредовала од позиције његоватељице до медицинске сестре, да има партнера Италијана, али и да је мајчин италијански језик скоро савршен. Друштвено напредовање мајке по доласку у Италију један је од начина да се скрене пажња на маргинализовану скупину његоватељица које су невидљиве у друштву. Иако је мајка интегрисана на помало идеализован начин у италијанско друштво, не представља Ани подршку нити позитиван примјер. Једини тренуци у којима се Ана осјећа блиском с мајком јесу они у којима разговарају на молдавском језику. Радња романа прати првих годину дана Аниног доласка у Италију. У том периоду, Ана одбија да учи италијански језик, споразумијева се углавном невербалном комуникацијом у ријетким тренуцима када уопште осјети потребу да нешто каже. Процес усвајања новог језика код Ане је пропраћен снажним осјећајем кривице према 
свом поријеклу. Када у разговору с баком почне да користи узвике својствене италијанском језику, Ана ће сањати да је заборавила молдавски и с њим властити идентитет. Италијански језик доживљава као језик инвазије који ју „тјера на заборав и замјену... [те] се чинило да је избор да напусти молдавски једини начин да може живјети“ (Мuјс̌ić 2012: 58). Молдавија и матерњи језик постају за Ану визија изгубљеног свијета сигурности, а када га чује на улицама Италије, оно што осјећа је комбинација среће и бола. Ријечи на италијанском језику добиће смисао тек када први пут почне да осјећа на том језику. Њен отпор ће се тада смањити и започеће процес креирања нове стварности у којој ће појмови и људи попримити контуре и смисао. Анино усвајање језика започиње учењем апстрактних именица и преписивањем пјесама италијанских пјесника који су јој неразумљиви, али јој неутралност овог поступка преписивања улијева сигурност. Ипак, њени осјећаји су амбивалентне природе, јер је, с једне стране, нова сазнања привлаче, док с друге осјећа срам због чињенице да присваја ријечи које у њиховој суштини не разумије, притом се одричући једине сигурне тачке коју има, а то је језик из којег потиче. Идеја језика као средства изградње нове стварности и новог идентитета у роману блиска је са записима саме ауторке о доживљају два језика којима припада. У ecejy „L’Altra“, ${ }^{3}$ ауторка се бави питањем живота на два језика, као и покретачком снагом коју језик има у изградњи идентитета, али и у односу с Другим. Идеју Другости Елвира Мујчић објашњава као нешто што носи у себи од раног дјетињства, кроз емотивну вриједност коју су одређене ријечи из дијалекта имале у односу на стандардни књижевни језик, попут ријечи за поздрав коју су користили њени бака и дјед, мерхаба, у односу на добар дан које су користиле васпитачице у вртићу. Свијест о Другости има и Ана, али се она сада преноси на однос између матерњег, молдавског и језика домаћина, италијанског језика. Ријеч сиромаштво, објасниће Ана, на молдавском има тежину тренутка када су отац и мајка, усљед политичких превирања изгубили посао, има срамоту похабаних ципела и тежину наука њених бака да се сиромаштво поносно носи, усправне главе, док ријеч сиромаштво на италијанском дјелује празно, јер не означава емотивно искуство. Другост унутар језика домаћина, написаће даље Мујчић, даје снагу да се из тог језика, који пружа утјеху и ред у хаосу, путује ка другој обали у процесу превођења, ка матерњем језику који је језик трауме и сиромаштва. У том језику, ауторка је свјесно зауставила процес одрастања, желећи да се заштити од боли коју је доживјела на матерњем језику, да би јој италијански постао средство којим ће властиту егзистенцијалну изгубљеност покренути ка изградњи новог идентитета. Сличан мотив, који је очито аутобиографске природе, препознајемо и у 
роману La lingua di Ana, у којем Ана, након што се нађе у међупростору два језика и два идентитета, схвати да опција „постојања између“ није могућа и пригрли језик домаћина као језик који уноси ред у хаотичност промјене средине. Као и у случају ауторке, језик домаћина за Ану има моћ да залијечи трауме проживљене на матерњем молдавском језику, попут одласка мајке као економског мигранта и распада брака њених родитеља због очеве невјере. Значајно је да се у роману на неколико мјеста помиње impasse, као врста егзистенцијалног међупростора у којем се нараторка налази, а који се простире између два језика, између земље поријекла и земље домаћина, између некадашњег идентитета и новог. У роману је чак постојање у овом међупростору временски дефинисано, поклапа се с Аниним доласком у Италију и првих годину дана боравка у овој земљи, у којима јој се чини да егзистира у некој врсти лимба, несвјесна стварности која је окружује. Карактеристике impasse-a на њу дјелују девастирајуће, али међупростор крије и огроман потенцијал јер је омеђен потрагом за језиком, за преласком на другу обалу, како то Елвира Мујчић дефинише у свом есеју о превођењу. Транснационални наративи управо у њему црпу своју снагу, јер је транснационални сензибилитет уједно и методологија и начин истраге: начин виђења и намерног незнања, начин живљења унутар простора између питања и одговора (Federici and Fortunati 2019: 52). Управо „бивање између“ даје могућност преиспитивања, учења о себи, али и о језику. Ово стање омогућава Ани да скупи снагу за поновно рађање, које се симболички одвија управо кроз усвајање језика домаћина:

Била сам бременита овим језиком, италијанским, и чекала сам да се развије, да угледам свјетлост дана, да дам живот овој Ани која није могла заувијек остати непомична у свом impasse-y. (Mujčić 2012: 119)

Из завршних редова романа сазнајемо да Ана успијева да се интегрише у земљу домаћина, те да се као млада научница бави биологијом, али и да и даље свакодневно изучава рјечник италијанског и молдавског језика који има функцију давања реда хаосу живота. Италијански језик за одраслу Ану која приповиједа остаје језик рационалности, на којем је ријетко осјетила неку емоцију, док је матерњи молдавски оличење висцералног (Мuјс̌ić 2012: 119). Флуидност идентитета одрасле Ане огледа се у свијести да начин на који јесмо није дефинитиван и непромјенљив. Њена разапетост између два простора јасно показује да се бивствовање дешава увијек из позиције Другог, али и да тако нестабилна позиција са собом доноси, с једне стране, недефинисаност, а, с друге, 
огроман стваралачки потенцијал. Јукстапозиција привлачења и одбијања коју доноси живот на другом језику, неће нестати, али ће се претворити у коегзистенцију два језика која омогућава објективнију тачку гледишта. Нове ријечи које усваја кроз језик, исприповиједаће Ана, „нас прожимају мијењајући нас, чинећи нас другачијим, удаљујући нас од оног што смо мислили да јесмо на имобилан и дефинитиван начин“ (Mujčić 2012: 63). Живот имигранткиње не стаје, он се наставља и управо захваљујући језику који пружа могућност нових доживљаја и контакта са Другим.

\section{Национално/транснационално}

У роману се идеја националног огледа у Анином доживљају граница. На неколико мјеста путовање преко граница изазива у њој осјећај тјескобе. У њеној пацифистичкој визији свијета у којој јасно доминира свијест о Другом, „географска ограничења су изум човјека користан само да нас убиједи да су унутар одређених граница људи бољи од оних који су изван њих“ (Мuјс̌ić 2012: 101). Идеја о нацији је такође иронизирана јер се доводи у питање смисао њеног постојања који пречесто почиње и завршава крвопролићима. Овакви ставови не заузимају централно мјесто у роману које ипак припада односу с језиком, али свакако теже редимензионирању свијета у којем ће управо наративи међупростора учинити легитимним питања о потреби за постојањем бинарности попут националног/транснационалног, личног/колективног, источног/западног и слично. Бавећи се мапирањем англофоних ауторки с простора бивше Југославије, Татјана Бијелић наглашава да ове књижевнице „у исто вријеме припадају англоамеричкој, постјугословенској и транснационалној прози, чиме се једнако усложњава и расвијетљава њихова позиција у ширим контекстима миграцијске књижевности“ (Bijelić 2017: 96). Аналогно томе, могуће је отворити питање припадања италофоних ауторки с простора бивше Југославије. Када је ријеч о присуству ових ауторки у италијанској књижевности, видјели смо да су студији миграцијске књижевности и даље недовољно заступљени да би учинили легитимним присуство ових гласова унутар самог канона. Ово питање је додатно усложњено очекивањем италијанских издавачких кућа да се ауторке попут Елвире Мујчић баве ратним искуством, односно колективним умјесто личног. Ауторке су често виђене као представнице земаља поријекла, које имају задатак да освијетле политичку ситуацију и друштвена питања земаља из којих долазе, док је истовремено њихов лични идентитет маргинализован. Ауторке, како тврди Бијелић, често праве компромисе између свог 
стваралачког израза и очекивања да постану глас националног колективитета, међутим, упркос уложеним напорима и постојањима наратива који настају у међупростору, горе наведене бинарности су и даље присутне (Bijelić 2017: 109). Роман Елвире Мујчић La lingua di Ana важан је, дакле, прије свега тематски, јер не говори о ратној Босни и Херцеговини, већ радња прати главни женски лик који потиче из Молдавије. Овим поступком, ауторка се директно опире очекивањима издавача, а њена прича поприма универзалан карактер миграцијског искуства. Полазећи из међупростора живота на два језика и у двије културе, овај роман нам је подсјетник да је у вријеме интензивних миграција постало недовољно и ограничавајуће размишљати искључиво у терминима националних књижевности и припадања истима. Транснационална и миграцијска књижевност су дисциплине које су релативно нове на европском простору, али свакако заслужују даље изучавање. У прилог тој тврдњи, роман Елвире Мујчић само је један од многобројних примјера гласова које не можемо дефинисати етикетом националног. Проза која приповиједа миграцијско искуство дјевојке из Молдавије у Италији, а коју је написала књижевница из Босне и Херцеговине која пише искључиво на италијанском језику потврђује своју припадност књижевности коју је најбоље дефинисала Дубравка Угрешић:

На питање шта је европско у европској књижевности, имам само један одговор, чија би најкраћа варијанта била: господин Батачараја, Индијац рођен у Калкути који живи у Њујорку и пише о Европи. (Ugrešić 2003: 172)

\section{Закључак}

Роман La lingua di Ana. Chi sei quando perdi radici e parole Елвире Мујчић отвара дијалог са читатељком/ем у којем доминантну улогу има питање идентитета на нематерњем језику, у земљи домаћина. Нови језик на којем се живи пружа могућност поновне изградње идентитета и прикупљања нових животних искустава. Предуслов за овај процес је креативни међупростор између два језика и двије културе, као и између старог и новог идентитета. Транснационални наративи почивају на том међупростору омогућавајући наративним гласовима флуидност идентитета, његову недефинисаност и константну свијест о драгоцјеном Другом. Роман се доминантно бави животом у језику и кроз језик, а мање друштвено-политичким околностима земље домаћина. Ипак, кроз неколико поглавља написаних с тачке гледишта Анине мајке, анализира се питање 
маргинализоване позиције економских имигранткиња, које углавном у улози његоватељица долазе да раде у Италију. Ова друштвена категорија је невидљива и ријетко има прилику потпуне интеграције. Овим поступком, ауторка проговара о темама које још увијек нису довољно присутне у транснационалној књижевности на италијанском језику и даје видљивост и глас имигранткињама које обављају значајан посао бриге о немоћнима.

\footnotetext{
${ }^{1}$ Роман је објављен у Италији 2012. године, али није доживио превод на било који од језика бивше Југославије. Све цитате с италијанског језика, укључујући и наслов романа, превела је ауторка овог текста.

2 Армандо Њиши заслужан је за прву књигу о миграцијској књижевности у Италији, La letteratura italiana della migrazione, која је објављена 1998. године, као и за прву онлајн базу података о дјелима и ауторима миграцијске књижевности на италијанском језику BASILI\&LIMM, https://basili-limm.el-ghibli.it/operecritiche.

3 https://rivistatradurre.it/laltra/?fbclid=IwAR2FVFr9br9ek8c3ZHiVh9gLbjUpORZWOB3dpyV-ekdppB1cvkAwugx2J8 (преузето 20. 8. 2021).
} 


\section{Литература}

Bijelić, Tatjana. „Transnacionalni modeli kontekstualizacije savremene ženske književnosti u dijaspori.“Folia linguistica et litteraria: Časopis za nauku o jeziku i književnosti, br. 17 (2017): 93-113.

Eleonora Federici and Vita Fortunati. „Theorizing Women's Transnational Literatures: Shaping New Female Identities in Europe trough Writing and Translation.“ U Times of Mobility. Transnational Literature and Gender in Translation, urednik Jasmina Lukić and Sibelan Forrester with Borbala Farago Forrester, 47-79. Budapest: CEU Press, 2019.

Friedman, Susan Stanford. Mappings. Feminism and the cultural Geographies of Encounter. Princeton, New Jersey: Princeton University Press, 1998.

Gnisci, Armando. Creolizzare l'Europa. Letteratura e migrazione. Roma: Meltemi, 2003.

Mujčić, Elvira. La lingua di Ana. Chi sei quando perdi radici e parole? Formigine (MO): Infinito edizioni, 2012.

Mujčić, Elvira. $\quad$ "L'altra". $\quad$ Tradurre br. 18 (2020). https://rivistatradurre.it/laltra/?fbclid=IwAR2FVFr9br9ek8c3ZHiVh9gLbjUpORZWOB3dpy V-ekd-ppB1cvkAwugx2J8 (преузето 20. 8. 2021).

Ugrešić, Dubravka. Thank You for Not Reading. Prevod: Celia Hawkesworth and Damion Searls. London: Dalkey Archive Press, 2003.

Vranceanu, Alexandra. „Letteratura transnazionale e opere di scrittori rumeni migranti.“ U Il romanzo rumeno contemporaneo (1989-2010). Teorie e proposte di lettura. Urednik Nicoleta Nesu, 83-102. Roma: Bagatto Libri, 2010. 
Sanja Kobilj Ćuić

sanja.kobilj@flf.unibl.org

University of Banja Luka

Faculty of Philology https://doi.org/10.18485/knjiz.2021.11.11.7

UDC: 821.131.1.09 Мујчић Е.

Original scientific article

\section{Identity and Language in a Novel by Elvira Mujčić}

In this paper we deal with the issue of transnational literature using the case of the author of Bosnian origin Elvira Mujčić who, as a representative of the so-called second generation of immigrant writers in Italy, writes and publishes exclusively in Italian. The paper pays special attention to the issue of language in the construction of identity, which the author deals with in one of her most important novels, La lingua di Ana. Chi sei quando perdi radici e parole. If we accept in theoretical terms one of the basic principles of transnational locational feminism (for which Susan Stanford Friedman, literary critic and author of the influential study Mappings, is credited) stating that a literary text creates theory, the novel Ana's Language can be considered a programmatic work that explores the question of language and its connection with identity, but also with the Other. The dominant idea in the novel is the coexistence of two languages as a possibility for creating a relationship with the Other, one that is different from us, which enables the fluidity of the heroine's identity, but also her rejection of binary categories of existence, which is in line with the basic settings of locational feminism. As we will try to show in the paper, the host's language has the additional function of rebirth after her traumatic exile from the language of her origin. As Elvira Mujčić is also actively involved in literary translation, we will consider her essay with the symbolic title "L'Altra”, in which she explains her own understanding of the coexistence of two languages, and the meaning and function of translation. Also, this paper tries to point out the need for a further mapping of diasporic literary voices, as well as the need for considering the status and recognition of female and male writers in the host country.

Keywords: identity, language, transnational, impasse 